Article

\title{
Phytochemical Profiling of Fruit Powders of Twenty Sorbus L. Cultivars
}

\author{
Kristina Zymone ${ }^{1,2}$, Lina Raudone ${ }^{1,2, *}$, Raimondas Raudonis ${ }^{1}$, Mindaugas Marksa ${ }^{3}$, \\ Liudas Ivanauskas ${ }^{3}$ and Valdimaras Janulis ${ }^{1}$ \\ 1 Department of Pharmacognosy, Lithuanian University of Health Sciences, Kaunas LT-50162, Lithuania; \\ kristigai@gmail.com (K.Z.); raimondas.raudonis@lsmuni.lt (R.R.); farmakog@lsmuni.lt (V.J.) \\ 2 Laboratory of Pharmaceutical Sciences, Institute of Pharmaceutical Technologies, \\ Lithuanian University of Health Sciences, Kaunas LT-50162, Lithuania \\ 3 Department of Analytical and Toxicological chemistry, Lithuanian University of Health Sciences, \\ Kaunas LT-50162, Lithuania; mindaugas.m.lsmu@gmail.com (M.M.); liudas.ivanauskas@lsmuni.lt (L.I.) \\ * Correspondence: lina.raudone@lsmuni.lt; Tel.: +370-682-41377
}

Academic Editor: Maria Carla Marcotullio

Received: 17 September 2018; Accepted: 5 October 2018; Published: 10 October 2018

\begin{abstract}
Rowanberries have been traditionally used in various processed foods. Scientific research demonstrates the pharmacological effects of Sorbus L. fruits are determined by their unique composition of biologically active compounds. The aim of this study was to determine the composition of flavonoids, phenolic acids, anthocyanins, carotenoids, organic acids and sugars as well as the total antioxidant activity in fruit powders of 20 Sorbus cultivars. Chemical profiles of rowanberry fruit powders vary significantly. Cultivars 'Burka', 'Likernaja', 'Dodong', and 'Fructo Lutea' distinguish themselves with exclusive phytochemical composition and high antioxidant activity. Fruit powders from 'Burka', 'Likernaja' contain the highest contents of anthocyanins while fruit powder samples from 'Fructo Lutea' and 'Dodong' contain the highest levels of phenolic acids, ascorbic acid and the lowest levels of fructose. Fruit powder samples from 'Dodong' also contain the highest levels of $\beta$-carotene and sorbitol and the lowest levels of malic acid. Cultivars 'Burka', 'Likernaja', 'Dodong', and 'Fructo Lutea' could be selected as eligible raw materials for the preparation of rowanberry fruit powders.
\end{abstract}

Keywords: Sorbus; fruit powders; phenolic compounds; carotenoids; sugars; organic acids

\section{Introduction}

The rowans (mountain-ashes) belong to the genus Sorbus L. and are widely distributed in the Northern hemisphere, extending to high northern latitudes [1]. Rowan trees are commonly used as ornamental plants in environmental management, as well as fecund fruit-bearing crops [2-5]. Rowanberries have been traditionally used in the diets of Northern Europeans in various processed foods such as jams, jellies and beverages that possess high nutritional and health-promoting potential [5-8]. Scientific studies have proven the anti-inflammatory [9], antioxidant [10], antidiabetic effects [11] that are determined by their unique composition of biologically active compounds-notable amounts of ascorbic acid, phenolic compounds, carotenoids, as well as organic acids and sugars $[3,7,8,12]$ Ascorbic acid, carotenoids, flavonoids, anthocyanins and especially phenolic acids significantly contribute to the antioxidant activity [13-17]. They can act as radical scavengers, reducing agents, chain-breaking antioxidants and inhibit lipid oxidation [8] and therefore, rowanberry extracts could be applied as the cost-effective natural antioxidants instead of the synthetic ones [10]. Rowanberries can also be regarded as a rich source of caffeoylquinic acids $[4,8,12,17]$. Scientific research demonstrates that caffeoylquinic acids can alleviate oxidative stress in various disease models 
and possess neuroprotective, cardioprotective, antihyperlipidemic, anti-inflammatory, antidiabetic, antiviral, antifungal, hepatoprotective effects $[11,18,19]$. Organic acids, sugars and their ratio determine the organoleptic properties of the fruit. The taste is a very important factor affecting consumers' demand [20]. The astringent and tart rowanberry taste is diminished in berries of Sorbus hybrids with various Rosaceae members such as Crataegus L., Aronia (L.) Pers., Pyrus L., Mespilus Bosc ex Spach [4]. Breeding programs resulted in hybrids easily grown in poor soil and low temperature environments $[3,4,7,12,21]$. The hybrid rowanberries have superior taste characteristics and produce larger fruits compared to wild rowanberries [4]. The taste and the quality strongly depend on the phytochemical composition and therefore determination of its qualitative and quantitative traits becomes of great importance. Bitterness that is characteristic to Sorbus cultivars, is notably reduced when fruits are being picked very late in the autumn as the freezing reduces bitterness and astringency [5]. Post-sharvest treatment ensuring convenient transportation, distribution and shelf-life prolongation and taste properties becomes of great importance. Packaging films and storage conditions modification significantly increase fruit quality but their positive impacts have limited duration $[2,3,22]$. Freeze drying or lyophilisation can not only significantly retain all the bioactive phytochemicals, but also prevent the detrimental effects of polyphenoloxidase and maintain the stability and functionality of the final product [22,23]. Comprehensive qualitative and quantitative characterization of plant matrix is the first step in defining food or functional ingredient [24].

The aim of this comparative study was to determine the composition of flavonoids, phenolic acids, anthocyanins, carotenoids, organic acids and sugars as well as the total antioxidant activity in fruit powders of 20 Sorbus cultivars and to elucidate the cultivars with particular phytochemical composition. The uniform growing conditions allow the phytochemical evaluations eliminating climatic and environmental impact. To the best of our knowledge, the phytochemical and antioxidant activity data concerning the fruits of certain rowanberry genotypes ('Dodong', 'Essenziani', 'Fructo Lutea', 'Kirsten Pink', 'White Swan', 'Nevezinskaja', 'Pendula Variegata', 'Rubinovaja', 'Sorbinka') have not been reported before.

\section{Results}

Neochlorogenic, chlorogenic, cryptochlorogenic acids and dicaffeoylquinnic acid derivative were detected in all rowanberry extracts tested (Table 1, Figure 1). The content of these caffeoylquinic acids among the tested cultivars varied significantly, up to 16-fold. Caffeoylshikimic acid and coumaroylquinic acid derivative were detected only in certain fruit powder samples.

Significant variation in flavonol profile was determined, depending on the rowanberry cultivar (Table 2, Figure 1). The triplet of rutin, hyperoside and isoquercitrin was detected in all rowanberry fruit powder samples. The presence of quercetin malonylglucoside, isorhamnetin rutinoside and quercetin dihexosides is cultivar specific, their significant differences in content were up to 88-fold.

Separated and identified compounds (cyanidin 3-galactoside, cyanidin 3-glucoside, cyanidin 3-arabinoside, peonidin 3-arabinoside and malvidin 3-arabinoside) formed specific profiles depending on the cultivar. Only cyanidin 3-galactoside was detected in all fruit powder samples (except 'Fructo Lutea') with the amounts varying up to 346-fold (Table 3, Figure 2). 
Table 1. Contents of phenolic acids ( $\mu \mathrm{g} / \mathrm{g}$ DW) in Sorbus fruit powder samples.

\begin{tabular}{|c|c|c|c|c|c|c|}
\hline \multirow[b]{2}{*}{ Cultivar } & \multicolumn{6}{|c|}{ Compound } \\
\hline & $\begin{array}{c}\text { Neochlorogenic } \\
\text { Acid }\end{array}$ & Chlorogenic Acid & $\begin{array}{c}\text { Cryptochlorogenic } \\
\text { Acid }\end{array}$ & $\begin{array}{c}\text { Caffeoylshikimic } \\
\text { Acid }\end{array}$ & $\begin{array}{c}\text { Coumaroylquinnic } \\
\text { Acid Derivative }\end{array}$ & $\begin{array}{c}\text { Dicaffeoylquinnic } \\
\text { Acid }\end{array}$ \\
\hline 'Alaja Krupnaja' & $1588 \pm 74 \mathrm{efg}^{1}$ & $1191 \pm 61 \mathrm{k}$ & $131 \pm 6 \mathrm{ijk}$ & $\mathrm{nd}^{2}$ & nd & $69 \pm 3 \mathrm{hi}$ \\
\hline 'Burka' & $2736 \pm 55 \mathrm{bc}$ & $2868 \pm 70 \mathrm{fgh}$ & $159 \pm 1$ ghi & nd & nd & $57 \pm 0 \mathrm{i}$ \\
\hline 'Businka' & $1722 \pm 51$ ef & $3130 \pm 90$ def & $138 \pm 7 \mathrm{hij}$ & $37 \pm 2 c$ & $39 \pm 1 \mathrm{e}$ & $302 \pm 6 c$ \\
\hline 'Dodong' & $13,351 \pm 178 \mathrm{a}$ & $3813 \pm 77 b$ & $1025 \pm 26 \mathrm{a}$ & $520 \pm 26 a$ & nd & $208 \pm 9$ ef \\
\hline 'Essenziani' & $1526 \pm 65 \mathrm{fg}$ & $2848 \pm 25$ fghi & $286 \pm 0 \mathrm{~d}$ & nd & $47 \pm 2 \mathrm{~d}$ & $353 \pm 3 b$ \\
\hline 'Fructo Lutea' & $13,879 \pm 689 a$ & $10,314 \pm 143 a$ & $957 \pm 11 b$ & $186 \pm 11 b$ & $73 \pm 1 \mathrm{a}$ & $1327 \pm 37 a$ \\
\hline 'Granatnaja' & $2555 \pm 73 c$ & $2425 \pm 6 \mathrm{i}$ & $142 \pm 1$ ghij & nd & nd & $85 \pm 1 \mathrm{hi}$ \\
\hline 'Kirsten Pink' & $2574 \pm 64 c$ & $3590 \pm 97 b c$ & $268 \pm 5$ de & nd & $55 \pm 2 c$ & $177 \pm 1 \mathrm{f}$ \\
\hline 'Konzentra' & $820 \pm 47 \mathrm{~h}$ & $1804 \pm 12 \mathrm{j}$ & $93 \pm 21$ & nd & nd & $91 \pm 1$ ghi \\
\hline 'Krasnaja Krupnoplodnaja' & $1660 \pm 108 \mathrm{efg}$ & $2798 \pm 20$ fghi & $119 \pm 13 \mathrm{jkl}$ & nd & nd & $196 \pm 8 \mathrm{f}$ \\
\hline 'Likernaja' & $2710 \pm 48 c$ & $2797 \pm 58$ fghi & $176 \pm 3 \mathrm{fg}$ & nd & nd & $59 \pm 1 \mathrm{i}$ \\
\hline 'Miciurinskaja Desertnaja' & $1770 \pm 12 \mathrm{edf}$ & $2707 \pm 57$ fghi & $119 \pm 1 \mathrm{jkl}$ & nd & nd & $71 \pm 2$ hi \\
\hline 'Nevezinskaja' & $892 \pm 161 \mathrm{~h}$ & $3543 \pm 451 \mathrm{bcd}$ & $102 \pm 15 \mathrm{kl}$ & nd & nd & $212 \pm 10$ ef \\
\hline 'Pendula Variegata' & $1922 \pm 82 \mathrm{edf}$ & $2690 \pm 53$ ghi & $268 \pm 6$ de & nd & nd & $241 \pm 3$ de \\
\hline 'Red Tip' & $2149 \pm 48$ cde & $2918 \pm 48$ efgh & $276 \pm 3$ de & $40 \pm 1 c$ & $39 \pm 0 \mathrm{e}$ & $298 \pm 15 c$ \\
\hline 'Rosina Variegata' & $1742 \pm 321 \mathrm{edf}$ & $3308 \pm 245$ cde & $170 \pm 21 \mathrm{fgh}$ & nd & nd & $214 \pm 33$ def \\
\hline 'Rubinovaja' & $1575 \pm 95 \mathrm{efg}$ & $2761 \pm 136$ fghi & $200 \pm 13 \mathrm{f}$ & $40 \pm 2 c$ & $39 \pm 2 \mathrm{e}$ & $128 \pm 18 \mathrm{~g}$ \\
\hline 'Sorbinka' & $1052 \pm 149 \mathrm{gh}$ & $2484 \pm 144 \mathrm{hi}$ & $245 \pm 21 \mathrm{e}$ & nd & nd & $103 \pm 2 \mathrm{gh}$ \\
\hline 'Titan' & $2347 \pm 30 \mathrm{~cd}$ & $2530 \pm 116 \mathrm{hi}$ & $132 \pm 0 \mathrm{ijk}$ & nd & nd & $91 \pm 5 \mathrm{ghi}$ \\
\hline 'White Swan' & $3335 \pm 236 b$ & $3087 \pm 145$ efg & $437 \pm 14 c$ & $29 \pm 0 c$ & $69 \pm 2 b$ & $254 \pm 2 \mathrm{~d}$ \\
\hline
\end{tabular}

${ }^{1}$ Averages marked in different letters in the columns show statistically significant difference (at $\left.p<0.05\right) ;{ }^{2}$ nd-not detected. 
Table 2. Contents of flavonoids ( $\mu \mathrm{g} / \mathrm{g} \mathrm{DW}$ ) in Sorbus fruit powder samples.

\begin{tabular}{|c|c|c|c|c|c|c|c|c|c|}
\hline \multirow[b]{2}{*}{ Cultivar } & \multicolumn{9}{|c|}{ Compound } \\
\hline & $\begin{array}{c}\text { Quercetin } \\
\text { Dihexoside1 }\end{array}$ & $\begin{array}{c}\text { Quercetin } \\
\text { Dihexoside2 }\end{array}$ & $\begin{array}{l}\text { Quercetin } \\
\text { Dihexoside3 }\end{array}$ & Rutin & Hyperoside & Isoquercitrin & $\begin{array}{l}\text { Quercetin Malonyl } \\
\text { Glucoside }\end{array}$ & $\begin{array}{l}\text { Isorhamnetin } \\
\text { Rutinoside }\end{array}$ & Astragalin \\
\hline 'Alaja Krupnaja' & $121 \pm 10 \mathrm{ij}^{1}$ & $146 \pm 10 \mathrm{e}$ & $\mathrm{nd}^{2}$ & $97 \pm 7 d$ & $88 \pm 6 \mathrm{e}$ & $210 \pm 15 b c$ & $69 \pm 6$ def & nd & $9 \pm 1 d$ \\
\hline 'Burka' & $113 \pm 1 \mathrm{ij}$ & $80 \pm 0$ hi & $52 \pm 0 \mathrm{e}$ & $62 \pm 0 \mathrm{gh}$ & $136 \pm 1 c$ & $180 \pm 5 d$ & $41 \pm 1 \mathrm{f}$ & $7 \pm 0 \mathrm{~h}$ & nd \\
\hline 'Businka' & $250 \pm 7 \mathrm{fg}$ & $122 \pm 6 \mathrm{f}$ & nd & $23 \pm 1 \mathrm{ij}$ & $35 \pm 2 \mathrm{j}$ & $61 \pm 20 \mathrm{~h}$ & $84 \pm 54$ cde & nd & nd \\
\hline 'Dodong' & nd & nd & $57 \pm 0 \mathrm{~d}$ & $8 \pm 0 \mathrm{k}$ & $67 \pm 2 \mathrm{fg}$ & $41 \pm 0 \mathrm{hi}$ & $69 \pm 2$ def & $220 \pm 7 b$ & nd \\
\hline 'Essenziani' & $276 \pm 9 \mathrm{ef}$ & $68 \pm 2 i$ & nd & $118 \pm 2 c$ & $19 \pm 0 \mathrm{k}$ & $13 \pm 1 \mathrm{j}$ & nd & nd & nd \\
\hline 'Fructo Lutea' & $212 \pm 2 \mathrm{~h}$ & $39 \pm 0 \mathrm{j}$ & nd & $33 \pm 7 \mathrm{i}$ & $43 \pm 0 \mathrm{ij}$ & $50 \pm 11$ hi & $33 \pm 1 \mathrm{fg}$ & $25 \pm 0 \mathrm{~g}$ & nd \\
\hline ‘Granatnaja' & $260 \pm 7 \mathrm{f}$ & $181 \pm 7 \mathrm{~d}$ & $52 \pm 0 \mathrm{e}$ & $51 \pm 1 \mathrm{~h}$ & $124 \pm 0 \mathrm{~d}$ & $156 \pm 2 \mathrm{e}$ & $49 \pm 0$ ef & $3 \pm 0 \mathrm{~h}$ & nd \\
\hline 'Kirsten Pink' & $515 \pm 12 b$ & $188 \pm 5 d$ & nd & $138 \pm 3 b$ & $173 \pm 1 \mathrm{a}$ & $115 \pm 0 \mathrm{f}$ & nd & nd & $13 \pm 0 c$ \\
\hline 'Konzentra' & $149 \pm 4 \mathrm{i}$ & $68 \pm 2 \mathrm{i}$ & nd & $24 \pm 0 \mathrm{ij}$ & $14 \pm 0 \mathrm{k}$ & $13 \pm 0 \mathrm{j}$ & nd & nd & nd \\
\hline 'Krasnaja Krupnoplodnaja' & $261 \pm 17 \mathrm{f}$ & $124 \pm 5 \mathrm{f}$ & nd & $27 \pm 5 \mathrm{ij}$ & $42 \pm 7 \mathrm{ij}$ & $46 \pm 5$ hi & $37 \pm 0 \mathrm{fg}$ & $3 \pm 1 \mathrm{~h}$ & nd \\
\hline 'Likernaja' & $131 \pm 3 \mathrm{i}$ & $99 \pm 2 \mathrm{~g}$ & $62 \pm 1 c$ & $65 \pm 1 \mathrm{~g}$ & $138 \pm 1 c$ & $192 \pm 2 \mathrm{~cd}$ & $34 \pm 1 \mathrm{fg}$ & $6 \pm 0 \mathrm{~h}$ & nd \\
\hline 'Miciurinskaja Desertnaja' & $218 \pm 6$ gh & $94 \pm 2 \mathrm{gh}$ & $99 \pm 4 \mathrm{a}$ & $33 \pm 1 \mathrm{i}$ & $172 \pm 5 \mathrm{a}$ & $235 \pm 7 \mathrm{a}$ & $322 \pm 9 \mathrm{a}$ & $176 \pm 7 c$ & $27 \pm 0 \mathrm{a}$ \\
\hline 'Nevezinskaja' & $147 \pm 18 \mathrm{i}$ & $43 \pm 6 j$ & nd & $8 \pm 0 \mathrm{k}$ & $59 \pm 4 \mathrm{gh}$ & $36 \pm 4 \mathrm{i}$ & nd & nd & nd \\
\hline 'Pendula Variegata' & $93 \pm 1 \mathrm{j}$ & $29 \pm 0 \mathrm{j}$ & nd & $31 \pm 1 \mathrm{i}$ & $121 \pm 2 d$ & $139 \pm 2 \mathrm{e}$ & $233 \pm 3 b$ & $144 \pm 6 \mathrm{~d}$ & $24 \pm 1 \mathrm{~b}$ \\
\hline 'Red Tip' & $280 \pm 7$ ef & $45 \pm 0 \mathrm{j}$ & nd & $211 \pm 6 \mathrm{a}$ & $98 \pm 5 \mathrm{e}$ & $82 \pm 3 g$ & $101 \pm 3 \mathrm{~cd}$ & $46 \pm 4 \mathrm{f}$ & nd \\
\hline 'Rosina Variegata' & $627 \pm 14 \mathrm{a}$ & $304 \pm 8 \mathrm{a}$ & nd & $84 \pm 2 \mathrm{ef}$ & $90 \pm 0 \mathrm{e}$ & $114 \pm 0 \mathrm{f}$ & $108 \pm 3 c$ & $9 \pm 1 \mathrm{~h}$ & $10 \pm 0 \mathrm{~d}$ \\
\hline 'Rubinovaja' & $320 \pm 13 \mathrm{~cd}$ & $260 \pm 1 b$ & $7 \pm 0 \mathrm{f}$ & $88 \pm 9$ de & $51 \pm 6 \mathrm{hi}$ & $105 \pm 3 \mathrm{f}$ & $60 \pm 8$ ef & $6 \pm 2 \mathrm{~h}$ & nd \\
\hline 'Sorbinka' & $308 \pm 5$ de & $30 \pm 2 j$ & $3 \pm 0 \mathrm{~g}$ & $17 \pm 0 \mathrm{ik}$ & $74 \pm 2 \mathrm{f}$ & $33 \pm 1 \mathrm{ij}$ & $44 \pm 1 \mathrm{f}$ & $64 \pm 0 \mathrm{e}$ & nd \\
\hline 'Titan' & $352 \pm 5 c$ & $221 \pm 5 c$ & $76 \pm 1 \mathrm{~b}$ & $74 \pm 2 \mathrm{fg}$ & $177 \pm 0 \mathrm{a}$ & $219 \pm 2 \mathrm{ab}$ & $66 \pm 0$ def & $7 \pm 0 \mathrm{~h}$ & nd \\
\hline 'White Swan' & $617 \pm 35 a$ & $226 \pm 15 c$ & $3 \pm 0 \mathrm{~g}$ & $72 \pm 1 \mathrm{fg}$ & $152 \pm 5 b$ & $148 \pm 4 \mathrm{e}$ & $332 \pm 6 \mathrm{a}$ & $264 \pm 16 a$ & $10 \pm 0 \mathrm{~d}$ \\
\hline
\end{tabular}


Table 3. Contents of anthocyanins, carotenoids ( $\mu \mathrm{g} / \mathrm{g} \mathrm{DW})$ and antioxidant activity ( $\mu \mathrm{mol} \mathrm{TE} / \mathrm{g}$ ) of Sorbus fruit powder samples.

\begin{tabular}{|c|c|c|c|c|c|c|c|c|}
\hline \multirow[b]{2}{*}{ Cultivar } & \multicolumn{8}{|c|}{ Compound } \\
\hline & $\begin{array}{c}\text { Cyanidin } \\
\text { 3-Galactoside }\end{array}$ & $\begin{array}{c}\text { Cyanidin } \\
\text { 3-Glucoside }\end{array}$ & $\begin{array}{c}\text { Cyanidin } \\
\text { 3-Arabinoside }\end{array}$ & $\begin{array}{c}\text { Peonidin } \\
\text { 3-Arabinoside }\end{array}$ & $\begin{array}{c}\text { Malvidin } \\
\text { 3-Arabinoside }\end{array}$ & $\beta$-Carotene & $\begin{array}{c}\text { Total } \\
\text { Carotenoids } \\
\end{array}$ & $\begin{array}{c}\text { Antioxidant } \\
\text { Activity }\end{array}$ \\
\hline 'Alaja Krupnaja' & $553 \pm 14 \mathrm{f}^{1}$ & $5 \pm 0 \mathrm{gh}$ & $0.33 \pm 0 \mathrm{f}$ & nd $^{2}$ & $3 \pm 0 \mathrm{~g}$ & $445 \pm 23$ ef & $1455 \pm 73 c$ & $101 \pm 3 \mathrm{k}$ \\
\hline 'Burka' & $5196 \pm 130 \mathrm{a}$ & $320 \pm 6 a$ & $1827 \pm 46 \mathrm{a}$ & $100 \pm 2 \mathrm{a}$ & $28 \pm 1 \mathrm{a}$ & $150 \pm 8 \mathrm{~h}$ & $498 \pm 5 \mathrm{f}$ & $464 \pm 12 \mathrm{a}$ \\
\hline 'Businka' & $248 \pm 6$ gh & $13 \pm 0 \mathrm{fg}$ & $5 \pm 0 \mathrm{f}$ & nd & $2 \pm 0 \mathrm{~h}$ & $435 \pm 22$ ef & $1119 \pm 23 d$ & $196 \pm 5 \mathrm{e}$ \\
\hline 'Dodong' & $91 \pm 2 \mathrm{ijk}$ & nd & $3 \pm 0 \mathrm{f}$ & nd & nd & $1262 \pm 7 a$ & $2659 \pm 133 a$ & $107 \pm 3 \mathrm{jk}$ \\
\hline 'Essenziani' & $78 \pm 2 \mathrm{ijk}$ & nd & $4 \pm 0 \mathrm{f}$ & nd & nd & $467 \pm 24$ de & $743 \pm 38$ e & $66 \pm 2 \mathrm{~m}$ \\
\hline 'Fructo Lutea' & nd & nd & nd & nd & nd & $520 \pm 13 c$ & $1323 \pm 34 \mathrm{c}$ & $323 \pm 8 b$ \\
\hline 'Granatnaja' & $3792 \pm 95 b$ & $251 \pm 5 c$ & $883 \pm 22 b$ & $45 \pm 1 c$ & $19 \pm 0 c$ & $361 \pm 18 \mathrm{~g}$ & $1097 \pm 55 \mathrm{~d}$ & $154 \pm 4 \mathrm{~g}$ \\
\hline 'Kirsten Pink' & $41 \pm 1 \mathrm{jk}$ & nd & $3 \pm 0 \mathrm{f}$ & nd & nd & $23 \pm 1 j$ & $39 \pm 2 \mathrm{~h}$ & $138 \pm 3 \mathrm{gh}$ \\
\hline 'Konzentra' & $90 \pm 2 \mathrm{ijk}$ & $1 \pm 0 \mathrm{~h}$ & $4 \pm 0 \mathrm{f}$ & nd & nd & $525 \pm 7 c$ & $1436 \pm 18 c$ & $26 \pm 10$ \\
\hline 'Krasnaja Krupnoplodnaja' & $309 \pm 8 \mathrm{~g}$ & $20 \pm 0 \mathrm{f}$ & $6 \pm 0 \mathrm{f}$ & nd & $2 \pm 0 \mathrm{gh}$ & $323 \pm 4 \mathrm{~g}$ & $1049 \pm 27 \mathrm{~d}$ & $107 \pm 3 \mathrm{jk}$ \\
\hline 'Likernaja' & $5165 \pm 129 a$ & $309 \pm 6 b$ & $1849 \pm 46 a$ & $92 \pm 2 b$ & $24 \pm 1 \mathrm{~b}$ & $102 \pm 5 \mathrm{i}$ & $237 \pm 6 \mathrm{~g}$ & $476 \pm 12 \mathrm{a}$ \\
\hline 'Miciurinskaja Desertnaja' & $1575 \pm 39 \mathrm{~d}$ & $132 \pm 3 d$ & $330 \pm 8 \mathrm{~d}$ & $35 \pm 1 \mathrm{~d}$ & $9 \pm 0 \mathrm{e}$ & $65 \pm 1 \mathrm{ij}$ & $143 \pm 4 \mathrm{gh}$ & $221 \pm 6 \mathrm{~d}$ \\
\hline 'Nevezinskaja' & $175 \pm 4$ ghij & nd & $6 \pm 0 \mathrm{f}$ & nd & $1 \pm 0 \mathrm{i}$ & $537 \pm 27 c$ & $1440 \pm 36 \mathrm{c}$ & $77 \pm 2 \mathrm{~lm}$ \\
\hline 'Pendula Variegata' & $92 \pm 2$ hijk & $8 \pm 0 \mathrm{gh}$ & $5 \pm 0 \mathrm{f}$ & nd & nd & $815 \pm 41 \mathrm{~b}$ & $2348 \pm 118 b$ & $80 \pm 2 \mathrm{~lm}$ \\
\hline 'Red Tip' & $15 \pm 0 \mathrm{k}$ & nd & nd & nd & nd & $62 \pm 3 \mathrm{ij}$ & $124 \pm 7 \mathrm{gh}$ & $49 \pm 1 \mathrm{n}$ \\
\hline 'Rosina Variegata' & $314 \pm 8 \mathrm{~g}$ & $34 \pm 1 \mathrm{e}$ & $10 \pm 0$ ef & nd & $4 \pm 0 \mathrm{f}$ & $418 \pm 11 \mathrm{f}$ & $983 \pm 15 d$ & $121 \pm 3 \mathrm{ij}$ \\
\hline 'Rubinovaja' & $1101 \pm 28 \mathrm{e}$ & $129 \pm 3 d$ & $56 \pm 1 \mathrm{e}$ & $5 \pm 0 \mathrm{f}$ & $3 \pm 0 \mathrm{fg}$ & $93 \pm 2 i$ & $161 \pm 8 \mathrm{gh}$ & $245 \pm 6 c$ \\
\hline 'Sorbinka' & $202 \pm 5$ ghi & nd & $10 \pm 0$ ef & nd & nd & $505 \pm 5 \mathrm{~cd}$ & $1423 \pm 18 c$ & $85 \pm 21$ \\
\hline ‘Titan' & $3175 \pm 79 c$ & $245 \pm 5 c$ & $632 \pm 16 c$ & $32 \pm 1 \mathrm{e}$ & $10 \pm 0 \mathrm{~d}$ & $100 \pm 2 \mathrm{i}$ & $217 \pm 3 \mathrm{~g}$ & $132 \pm 3 \mathrm{hi}$ \\
\hline 'White Swan' & $26 \pm 1 \mathrm{jk}$ & nd & nd & nd & nd & $87 \pm 5 \mathrm{i}$ & $108 \pm 6 \mathrm{gh}$ & $170 \pm 4 \mathrm{f}$ \\
\hline
\end{tabular}

${ }^{1}$ Averages marked in different letters in the columns show statistically significant difference (at $\left.p<0.05\right) ;{ }^{2}$ nd-not detected. 


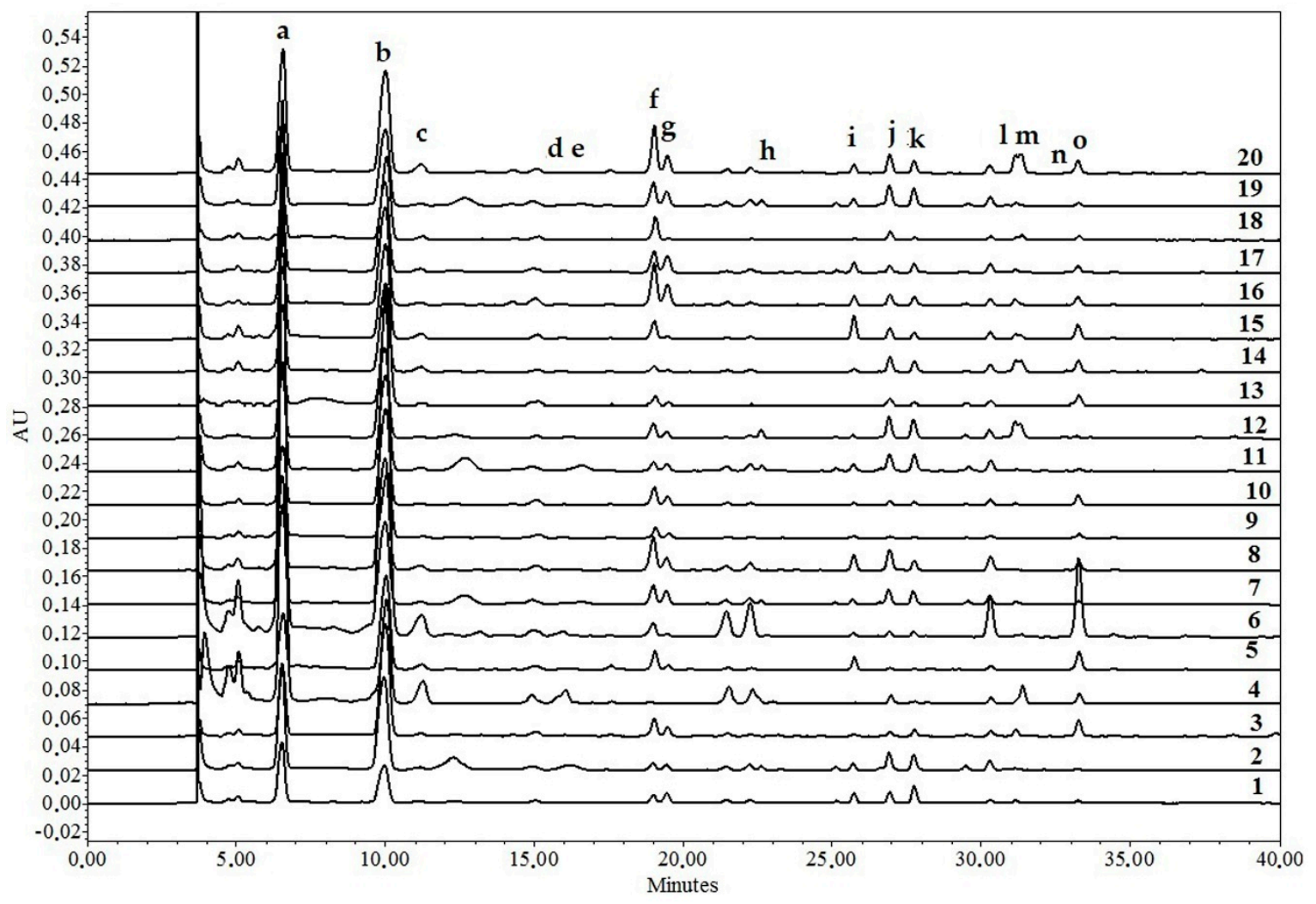

Figure 1. Phenolic compound profiles of different Sorbus fruit powder samples. a-neochlorogenic acid; b-chlorogenic acid; c-cryptochlorogenic acid; d-caffeoylshikimic acid; e-coumaroylquinnic acid derivative; $\mathrm{f}$-quercetin dihexoside1; g-quercetin dihexoside2; $\mathrm{h}$-quercetin dihexoside3; $\mathrm{i}$-rutin; $\mathrm{j}$-hyperoside; $\mathrm{k}$-isoquercitrin; 1 -quercetin malonylglycoside; $\mathrm{m}$-isorhamnetin rutinoside; n-astragalin; o-dicaffeoylquinnic acid. 1-'Alaja Krupnaja'; 2-'Burka'; 3-'Businka'; 4-'Dodong'; 5-'Esseziani'; 6-'Fructo Lutea'; 7-'Granatnaja'; 8-'Kirsten Pink'; 9-'Konzentra'; 10-'Krasnaja Krupnoplodnaja'; 11—'Likernaja'; 12-'Miciurinskaja Desertnaja'; 13-'Nevezinskaja'; 14-'Pendula Variegata'; 15-'Red Tip'; 16-'Rosina Variegata'; 17-'Rubinovaja'; 18-'Sorbinka'; 19—'Titan'; 20-'White Swan'.

The total content of carotenoids in the powder samples of Sorbus fruits varied within a wide range (up to 68 fold) (Table 3) with the highest amounts, as well as $\beta$-carotene, determined in 'Dodong' fruit powders.

Fructose, glucose and sugar alcohol sorbitol were detected in all fruit powder samples (Table 4). Sucrose was detected only in fruit powder samples from 'Alaja Krupnaja' and 'Granatnaja'. Malic acid was identified in all fruit powder samples. Ascorbic acid was absent in the fruit powder samples of 'Burka', 'Businka' and 'Likernaja' cultivars. Fruit powder samples from 'Businka', 'Dodong', 'Miciurinskaja Desertnaja', 'Konzentra' and 'Nevezinskaja' had the highest sugar/organic acid ratio and might be considered the sweetest fruits. Fruits of 'White Swan', 'Rosina Variegata', 'Fructo Lutea', 'Esseziani' and 'Kirsten Pink' had the lowest sugar/organic acid ratio (below 5) and might be described as sourest tasting fruits. These cultivars are mainly used as ornamental species.

The determined antioxidant activity ranged from 26 to $476 \mathrm{mmol} \mathrm{TE} \mathrm{kg}^{-1}$ (Table 3). Antioxidant activity has a moderate positive correlation with the total content of phenolic compounds. There was a strong positive correlation between antioxidant activity and the contents of cyanidin 3-galactoside $(r=0.725)$, cyanidin 3-glucoside $(r=0.704)$, cyanidin 3-arabinoside $(r=0.789)$, malvidin 3-arabinoside $(r=0.751)$, peonidin 3-arabinoside $(r=0.799)$. It could be concluded that anthocyanins have the highest contribution to the antioxidant activity. No significant correlations were determined between antioxidant activity and contents of other investigated compounds. 
Table 4. Contents of sugars and organic acids (mg/g DW) in Sorbus fruit powder samples.

\begin{tabular}{|c|c|c|c|c|c|c|c|c|}
\hline \multirow{2}{*}{ Cultivar } & \multicolumn{7}{|c|}{ Compound } & \multirow{2}{*}{ Sugars/Acids Ratic } \\
\hline & Xylose & Fructose & Glucose & Sucrose & Sorbitol & Ascorbic Acid & Malic Acid & \\
\hline 'Alaja Krupnaja' & $13.55 \pm 0.36 \mathrm{a}^{1}$ & $159.43 \pm 1.17 \mathrm{c}$ & $165.20 \pm 6.37 \mathrm{f}$ & $4.50 \pm 0.53 \mathrm{a}$ & $190.38 \pm 2.95 \mathrm{~g}$ & $0.24 \pm 0.00 \mathrm{j}$ & $59.67 \pm 0.44 \mathrm{~g}$ & $8.90 \pm 0.10 \mathrm{f}$ \\
\hline 'Burka' & $6.77 \pm 0.64 \mathrm{~cd}$ & $130.97 \pm 2.08 \mathrm{f}$ & $144.71 \pm 1.33 \mathrm{~g}$ & $\mathrm{nd}^{2}$ & $158.36 \pm 1.88 \mathrm{i}$ & nd & $77.22 \pm 0.88 \mathrm{~d}$ & $5.71 \pm 0.01 \mathrm{j}$ \\
\hline 'Businka' & nd & $149.41 \pm 3.72 \mathrm{~d}$ & $186.96 \pm 0.42 \mathrm{~cd}$ & nd & $235.75 \pm 4.32 \mathrm{de}$ & nd & $44.30 \pm 0.36 \mathrm{k}$ & $12.91 \pm 0.09 a$ \\
\hline 'Dodong' & $6.68 \pm 0.53 \mathrm{~cd}$ & $28.37 \pm 0.84 \mathrm{n}$ & $219.73 \pm 2.96 \mathrm{a}$ & nd & $252.27 \pm 1.79 c$ & $1.70 \pm 0.00 \mathrm{c}$ & $38.35 \pm 0.171$ & $12.66 \pm 0.10 \mathrm{a}$ \\
\hline 'Essenziani' & $13.98 \pm 1.34 \mathrm{a}$ & $79.02 \pm 4.18 \mathrm{jk}$ & $90.51 \pm 3.83 j$ & nd & $121.18 \pm 5.06 \mathrm{k}$ & $0.52 \pm 0.00 \mathrm{~h}$ & $73.14 \pm 1.14 \mathrm{e}$ & $4.14 \pm 0.13 \mathrm{k}$ \\
\hline 'Fructo Lutea' & $14.13 \pm 0.13 \mathrm{a}$ & $18.45 \pm 0.47 \mathrm{o}$ & $157.13 \pm 0.57 \mathrm{f}$ & nd & $196.31 \pm 0.05 \mathrm{~g}$ & $2.20 \pm 0.02 \mathrm{a}$ & $97.14 \pm 0.04 \mathrm{~b}$ & $3.89 \pm 0.01 \mathrm{k}$ \\
\hline 'Granatnaja' & $8.07 \pm 0.31 \mathrm{~cd}$ & $180.38 \pm 1.15 \mathrm{a}$ & $221.07 \pm 1.79 \mathrm{a}$ & $3.19 \pm 0.10 b$ & $188.84 \pm 1.40 \mathrm{~g}$ & $0.20 \pm 0.00 \mathrm{k}$ & $60.88 \pm 0.35 \mathrm{~g}$ & $9.85 \pm 0.02 \mathrm{de}$ \\
\hline 'Kirsten Pink' & $9.24 \pm 0.01 \mathrm{bc}$ & $56.87 \pm 1.601$ & $67.35 \pm 1.33 \mathrm{k}$ & nd & $192.50 \pm 0.42 \mathrm{~g}$ & $1.42 \pm 0.01 \mathrm{~d}$ & $76.15 \pm 0.04 \mathrm{~d}$ & $4.20 \pm 0.04 \mathrm{k}$ \\
\hline 'Konzentra' & nd & $110.67 \pm 0.74 \mathrm{~h}$ & $123.21 \pm 0.68 \mathrm{~h}$ & nd & $261.78 \pm 2.87 \mathrm{ab}$ & $0.36 \pm 0.00 \mathrm{i}$ & $43.95 \pm 0.03 \mathrm{k}$ & $11.19 \pm 0.09 c$ \\
\hline 'Krasnaja Krupnoplodnaja' & $5.10 \pm 0.04 \mathrm{~d}$ & $134.29 \pm 1.49$ ef & $160.95 \pm 1.78 \mathrm{f}$ & nd & $191.47 \pm 2.18 \mathrm{~g}$ & $0.59 \pm 0.00 \mathrm{~g}$ & $65.29 \pm 0.31 \mathrm{f}$ & $7.47 \pm 0.05 \mathrm{~h}$ \\
\hline 'Likernaja' & nd & $147.80 \pm 0.44 \mathrm{~d}$ & $178.86 \pm 0.33 \mathrm{de}$ & nd & $216.06 \pm 0.48 \mathrm{f}$ & nd & $54.58 \pm 1.05 \mathrm{~h}$ & $9.95 \pm 0.17 \mathrm{de}$ \\
\hline 'Miciurinskaja Desertnaja' & nd & $161.05 \pm 0.82 \mathrm{c}$ & $174.33 \pm 0.18 \mathrm{e}$ & nd & $240.84 \pm 1.77 \mathrm{~d}$ & $0.11 \pm 0.00 \mathrm{~m}$ & $47.90 \pm 0.87 j$ & $12.01 \pm 0.28 \mathrm{~b}$ \\
\hline 'Nevezinskaja' & $4.60 \pm 0.35 \mathrm{~d}$ & $122.26 \pm 1.76 \mathrm{~g}$ & $138.73 \pm 1.19 \mathrm{~g}$ & nd & $254.26 \pm 1.52 \mathrm{bc}$ & $0.38 \pm 0.00 \mathrm{i}$ & $50.91 \pm 0.26 \mathrm{i}$ & $10.14 \pm 0.04 \mathrm{~d}$ \\
\hline 'Pendula Variegata' & $13.12 \pm 0.15 \mathrm{ab}$ & $72.24 \pm 0.93 \mathrm{k}$ & $87.00 \pm 0.44 j$ & nd & $265.31 \pm 3.80 \mathrm{a}$ & $0.15 \pm 0.001$ & $44.69 \pm 0.27 \mathrm{k}$ & $9.76 \pm 0.06 \mathrm{e}$ \\
\hline 'Red Tip' & $5.52 \pm 5.52 \mathrm{~cd}$ & $82.39 \pm 0.20 j$ & $102.18 \pm 0.70 \mathrm{i}$ & nd & $231.53 \pm 0.79 \mathrm{e}$ & $0.91 \pm 0.00 \mathrm{f}$ & $60.19 \pm 0.38 \mathrm{~g}$ & $6.90 \pm 0.13 \mathrm{i}$ \\
\hline 'Rosina Variegata' & $7.14 \pm 0.06 \mathrm{~cd}$ & $99.67 \pm 3.70 \mathrm{i}$ & $109.53 \pm 2.05 \mathrm{i}$ & nd & $103.92 \pm 0.79 \mathrm{i}$ & $1.07 \pm 0.00 \mathrm{e}$ & $102.37 \pm 0.93 a$ & $3.10 \pm 0.041$ \\
\hline 'Rubinovaja' & $6.62 \pm 0.33 \mathrm{~cd}$ & $187.28 \pm 0.80 \mathrm{a}$ & $207.83 \pm 1.15 b$ & nd & $162.90 \pm 0.61 \mathrm{hi}$ & $0.21 \pm 0.00 \mathrm{k}$ & $63.62 \pm 0.79 \mathrm{f}$ & $8.85 \pm 0.07 \mathrm{f}$ \\
\hline 'Sorbinka' & $5.85 \pm 0.56 \mathrm{~cd}$ & $139.29 \pm 8.17 \mathrm{e}$ & $146.57 \pm 3.26 \mathrm{~g}$ & nd & $210.87 \pm 5.49 \mathrm{f}$ & $0.60 \pm 0.00 \mathrm{~g}$ & $50.65 \pm 0.67 \mathrm{i}$ & $9.81 \pm 0.19 \mathrm{de}$ \\
\hline 'Titan' & $6.16 \pm 0.24 \mathrm{~cd}$ & $169.18 \pm 0.49 b$ & $188.33 \pm 7.57 \mathrm{c}$ & nd & $169.17 \pm 1.05 \mathrm{~h}$ & $0.20 \pm 0.00 \mathrm{k}$ & $64.29 \pm 0.04 \mathrm{f}$ & $8.26 \pm 0.12 \mathrm{~g}$ \\
\hline 'White Swan' & $9.16 \pm 0.35 b c$ & $48.10 \pm 0.72 \mathrm{~m}$ & $53.37 \pm 0.211$ & nd & $146.34 \pm 0.23 j$ & $1.94 \pm 0.02 b$ & $81.27 \pm 1.18 c$ & $3.09 \pm 0.031$ \\
\hline
\end{tabular}

${ }^{1}$ Averages marked in different letters in the columns show statistically significant difference (at $\left.\mathrm{p}<0.05\right)^{2}$ nd-not detected. 


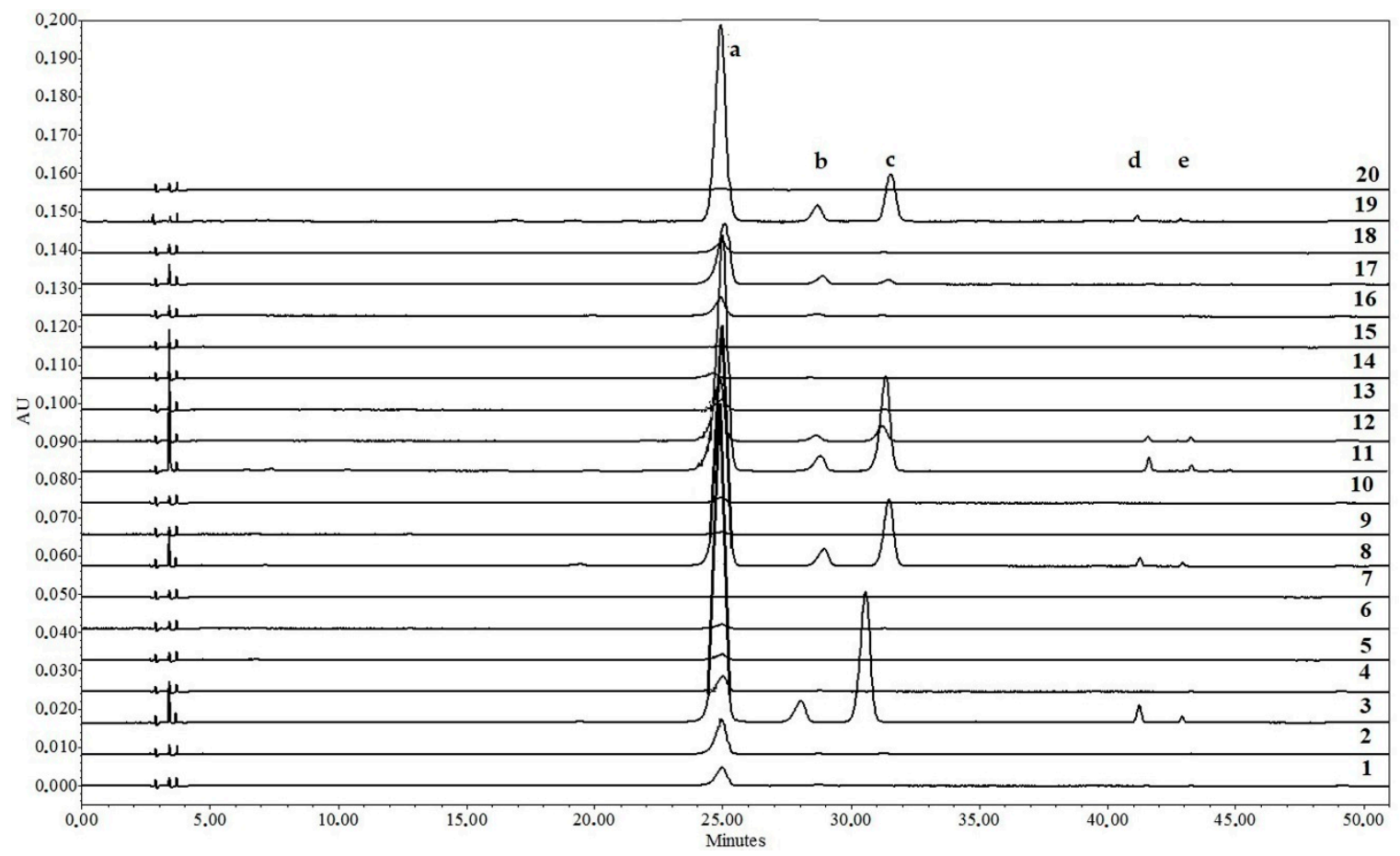

Figure 2. Anthocyanin compound profiles of different Sorbus fruit powder samples. a-cyanidin 3-O-galactoside; b-cyanidin 3-O-glucoside; c-cyanidin 3-O-arabinoside; $d$-peonidin 3-O-arabinoside; e-Malvidin 3-O-arabinoside. 1-'Alaja Krupnaja'; 2-'Burka'; 3-'Businka'; 4-'Dodong'; 5-'Esseziani'; 6-'Fructo Lutea'; 7-'Granatnaja'; 8-'Kirsten Pink'; 9-'Konzentra'; 10-'Krasnaja Krupnoplodnaja'; 11—'Likernaja'; 12—'Miciurinskaja Desertnaja'; 13-'Nevezinskaja'; 14-'Pendula Variegata'; 15-'Red Tip'; 16-'Rosina Variegata'; 17—'Rubinovaja'; 18—'Sorbinka'; 19-'Titan'; 20_'White Swan'.

A principal component analysis (PCA) of phenolic compounds in the rowanberry powder samples was performed (Figure 3). Four principal components explaining $89.17 \%$ of the total data variance were used for the in-depth analysis. The PCA indicated that anthocyanins had the greatest influence on the scores of the fruits (Figure 3). The first principal component differentiates fruit samples containing highest levels of anthocyanins. Fruit powder samples from 'Burka' and 'Likernaja' were distanced from all the others and were grouped at the positive side of the first principal component. These fruit powder samples contained the highest contents of anthocyanins. The second principal component differentiates fruit powder samples from 'Fructo Lutea' and 'Dodong'. These fruit powder samples contain the highest levels of phenolic acids, ascorbic acid and the lowest levels of fructose. The third principal component differentiates fruit powder samples from 'Dodong'. These fruit powder samples contain the highest levels of $\beta$-carotene and sorbitol and the lowest levels of malic acid. The fourth principal component differentiates fruits powder samples containing the highest contents of hyperoside and isoquercitrin. Fruit powder samples from 'Miciurinskaja Desertnaja', 'Titan', 'Kirsten Pink' and 'White Swan' were distanced from all the others and were grouped at the positive side of the fourth principal component. The most fruit powder samples were located near the zero point of principal components. Phytochemical compositions of these fruit powder samples were similar and contents of compounds were close to the mean values. 

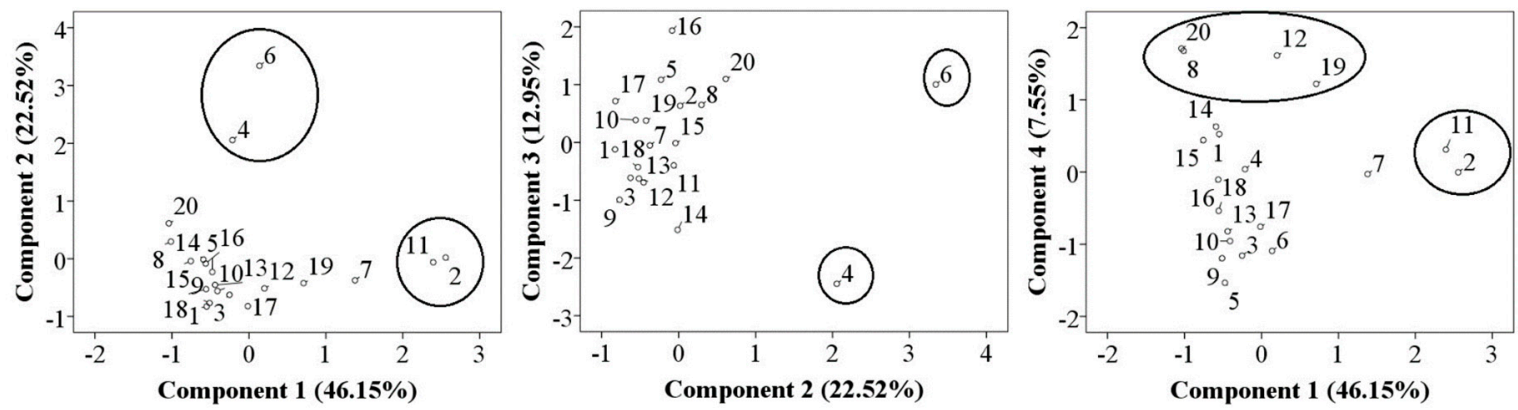

Figure 3. PCA score plots of different Sorbus fruit powder samples. 1-'Alaja Krupnaja'; 2-'Burka'; 3-'Businka'; 4-'Dodong'; 5-'Esseziani'; 6-'Fructo Lutea'; 7-'Granatnaja'; 8-'Kirsten Pink'; 9-'Konzentra'; 10-'Krasnaja Krupnoplodnaja'; 11-'Likernaja'; 12-'Miciurinskaja Desertnaja'; 13-'Nevezinskaja'; 14-Pendula Variegata'; 15—'Red Tip'; 16-'Rosina Variegata'; 17—'Rubinovaja'; 18-'Sorbinka'; 19—'Titan'; 20—'White Swan'.

After hierarchical cluster analysis, the rowanberry fruit samples were grouped into five clusters (Figure 4). Statistically significant differences were revealed among these five clusters. The first cluster was comprised exclusively of $S$. aucuparia cultivars. The fruit samples of this cluster were distinguished by one of the highest total content of sugars and by the lowest total contents of organic acid, phenolic acids and flavonoids. The second cluster was comprised exclusively of Sorbus hybrids. The fruit powder samples ascribed to the second cluster accumulated the highest content of anthocyanins, sugars, and the lowest content of carotenoids and phenolic acids. The third cluster was comprised of fruit powder samples of Lombart's hybrid ('Kirsten Pink', 'Red Tip', 'White Swan'), 'Esseziani' and 'Rosina Variegata'. In the fruit powder samples of these cultivars one of the highest total content of flavonoids and one of the lowest contents of anthocyanins, carotenoids and sugars were determined. To the fourth cluster, only 'Dodong' was attributed, which distinguished by the highest total content of carotenoids, sugars, and one of the lowest total contents of flavonoids and organic acids. The fifth cluster was comprised exclusively from 'Fructo Lutea'. The fruit powder samples of this cultivar were distinguished by the highest total contents of phenolic acids, organic acids and notable amounts of carotenoids.

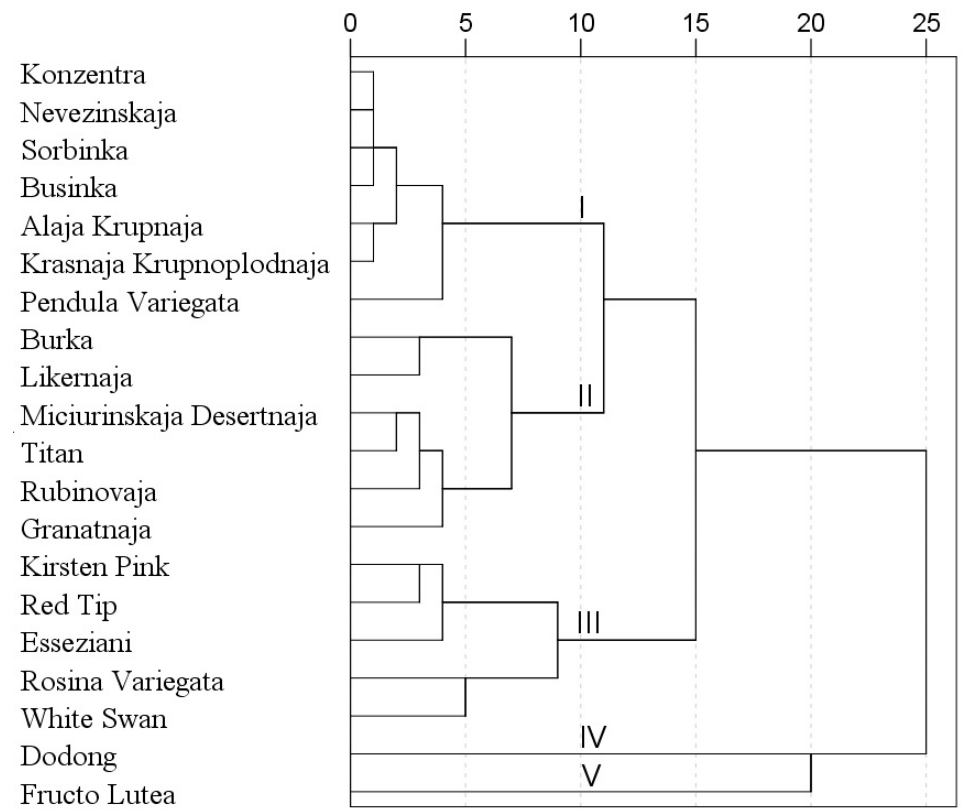

Figure 4. Dendrogram of the similarity of Sorbus fruit powder samples according to their phytochemical composition. 


\section{Discussion}

Sorbus fruits (rowanberries) are unique fruits with a rich composition of phytocompounds of various chemical origin $[4,8,12]$. Currently, more knowledge regarding the phytocomposition and health effects of Sorbus fruits is emerging [8,25], although these health promoting fruits are still underrated. Promotion of Sorbus species and incorporating their fruits in food and pharmaceutical industries could address the consumer's concerns over the safety and functionality of foods and health promoting supplements, as Sorbus plants are easily cultivated and are appropriate for areas with lower temperatures and poor soil environments [12]. Rowanberries are extremely rich in hydroxycinnamates with the amounts in certain cultivars equivalent to the amounts determined in coffee [26]. The amount of neochlorogenic and chlorogenic acids in other tested fruit powder samples ranged to $3813 \mathrm{mg} \cdot \mathrm{kg}^{-1}$, however, the contents of neochlorgenic and chlorogenic acids in fruit powder samples from 'Burka', 'Granatnaja' and 'Titan' are lower than previously determined by Kylli et al. [8]. Mattila et al., determined the greatest amounts of phenolic acids in rowanberries compared to samples of chokeberry, blueberry, saskatoon berry, bilberry, cloudberry, rose hip, raspberry, lingonberry, black currant and bog whortleberry [27]. Caffeoylquinic acids possess a body of biological activities including inhibition of $\alpha$-glucosidase, anti-inflammatory, cardioprotective, neuroprotective and antioxidant activity as well [19]. Chlorogenic and neochlorogenic acids are proposed as markers of phytochemical and antioxidant profiles of Sorbus fruits [17] as they are detected in the samples of all rowanberry cultivars. Certain predominant compounds of anthocyanin profiles could also serve as markers for sweet rowanberries. The high concentrations of anthocyanins are constituted from levels present in wild rowanberries and levels complemented from crossing partners [4]. The total contents of anthocyanins in fruit powder samples varied within wider ranges, compared to the Kylli et al. [8] and Hukkanen et al. [4] studies. The predominant component in the composition of anthocyanins in the fruit powder samples was cyanidin 3-galactoside (Table 3). According to the scientific data extracts rich in anthocyanins could be used in order to prevent and control obesity [28], dyslipidemia, diabetes [29], improve vision [30], reduce inflammation [31].

Carotenoids in rowanberries are mainly composed of $\beta$-carotene and cryptoxanthin [32]. Literature data indicate that the content in rowanberry cultivars vary from $10 \mathrm{mg} \cdot \mathrm{kg}^{-1} \mathrm{up}$ to $104 \mathrm{mg} \cdot \mathrm{kg}^{-1}$ [12,21]. Mikulic-Petkovsek et al. distinguished 'Krasavica' and 'Burka' as carotenoid-rich cultivars with total data showing carotenoid amounts of 84.5 and $85.1 \mathrm{mg} \cdot \mathrm{kg}^{-1}$ [12]. Our results demonstrate that 'Burka' fruits powders contain $498 \mathrm{mg} \cdot \mathrm{kg}^{-1}$ of total carotenoids. The phytochemical composition is determined not only by cultivar, but also by geographic origin, growing conditions and other factors [2]. Carotenoids are potent quenchers of singlet oxygen, and additionally they efficiently scavenge other reactive oxygen species. Evidence based scientific data promote intake of carotenoids that significantly reduces the risk of chronic diseases $[15,16,33]$. Carrots have the highest carotene content among human foods [34]. Certain rowanberry cultivars can be regarded as a rich source of carotenoids as well as carrots [21].

Organoleptic properties of fruits are mainly determined by volatile compounds, sugars, organic acids and their ratios. Their content is very important for the consumers with special requirements, as well as it affects processing techniques [35]. Mikulic-Petkovsek et al. determined that the predominant sugar component is glucose, whereas in our study sorbitol was the prevailing component in the sugar composition of all fruit powder samples except 'Granatnaja', 'Rosina Variegata', 'Rubinovaja' and 'Titan' [12]. Chukwuma and Islam determined that sorbitol contributes to glycaemic control effects by inhibiting intestinal glucose absorption and increasing muscle glucose uptake [36]. Consequently, rowanberry fruit powders have potential as diabetic food ingredients. Not all fruit powder samples of the tested cultivars contained sucrose (Table 5). This is in agreement with Mikulic-Petkovsek et al. In our study sucrose was detected only in fruit powder samples from 'Alaja Krupnaja' (4.50 $\left.\pm 0.53 \mathrm{~g} \cdot \mathrm{kg}^{-1}\right)$ and 'Granatnaja' (3.19 $\left.\pm 0.10 \mathrm{~g} \cdot \mathrm{kg}^{-1}\right)$ [12]. Malic acid is the main contributor to total organic acids. Mikulic-Petkovsek et al. determined the predominant amounts of malic acid in rowanberries and distinguished them as the fruits with the highest content of total 
analyzed organic acids, followed by jostaberry, lingonberry, black currant, red gooseberry, and kiwifruit [20].

Ascorbic acid is regarded as the nutrient quality indicator during processing and storage. If the amounts of ascorbic acid is well-retained, the other nutrients could be retained in matrices with minimum losses, as well [37]. It is important to note that not all fruit powder samples of the tested Sorbus cultivars contained ascorbic acid. 'Fructo Lutea', 'Dodong', 'White Swan' and 'Kirsten Pink' were the cultivars with ascorbic acid determined in a range of $1.42-2.20 \mathrm{~g} \cdot \mathrm{kg}^{-1}$ (DW). These cultivars might be regarded as a rich source of vitamin $C$, as compared to other fruits, known sources of vitamin $C$ e.g., cranberries $\left(1.34 \mathrm{~g} \cdot \mathrm{kg}^{-1} \mathrm{DW}\right)$ [37]. Ascorbic acid is a very processing-sensitive compound. Shofian et al. determined that freeze-drying can be used to retain the maximum amount of ascorbic acid as the low temperature processing has minimal deteriorating effects. Freeze drying is an excellent technique for preparation of fruit powders containing heat-sensitive antioxidant components [38]. Freeze drying ensures the retention of complete phytochemical complex and maintenance of the stability and the functionality of the product until utilization, as well as preserves color and texture of fruits.

\section{Materials and Methods}

Sorbus L. cultivars were grown in the northern region of Lithuania at the arboretum of Rūta Stankūnienè in Linkaičiai, Joniškis district $\left(56^{\circ} 12^{\prime} 00^{\prime \prime} \mathrm{N} 23^{\circ} 28^{\prime} 41^{\prime \prime} \mathrm{E}\right)$. The region is in the temperate climate zone and the sub-region of Atlantic-European continental mixed and broad-leaved forests. Characteristics of climate region: the average annual temperatures $6.5-7{ }^{\circ} \mathrm{C}$; the annual minimum and maximum temperatures $-33^{\circ} \mathrm{C}$ and $+35^{\circ} \mathrm{C}$; the annual precipitation amount-560-700 mm; snow coverage in days-75-90; sunshine duration hours-1750-1850. The experimental orchard was not irrigated. Samples of 'Esseziani', 'Alaja Krupnaja', 'Burka', 'Businka', 'Dodong', 'Fructo Lutea', 'Granatnaja', 'Kirsten Pink', 'Konzentra', 'Krasnaja Krupnoplodnaja', 'Likernaja', 'Miciurinskaja Desertnaja', 'Nevezinskaja', 'Pendula Variegata', 'Red Tip', 'Rosina Variegata', 'Rubinovaja', 'Sorbinka', 'Titan', 'White Swan' were collected at full maturity stage determined by horticulturist based on fruit color, flavor, and firmness (2014, September). Description of tested rowanberry species and cultivars are displayed in Table 5 . The fruits after collection were immediately frozen and subjected to lyophilisation. The rowanberry powder sample was comprised of $0.5 \mathrm{~kg}$ fruits of each cultivar. The collected fruits were lyophilised with a ZIRBUS sublimator $3 \times 4 \times 5 / 20$ (ZIRBUS Technology, Bad Grund, Germany) at a pressure of 0.01 mbar (condenser temperature, $-85^{\circ} \mathrm{C}$ ) and stored in a dark, dry place. The lyophilized fruits were ground to a fine powder by using a Retsch 200 mill (Haan, Germany). The research results were re-calculated for dry raw plant material.

\subsection{Materials and Reagents}

Analytical and chromatographic grade reagents were used for this study: acetonitrile, neochlorogenic acid, cryptochlorogenic acid, quercetin 3-O-(6"-O-malonyl)- $\beta$-D-glucoside (quercetin malonylglucoside in text), isorhamnetin 3-O-rutinoside, cyanidin 3-O-galactoside, cyanidin 3-O-glucoside, cyanidin 3-O-arabinoside, $\beta$-carotene, ascorbic acid, malic acid, fructose, glucose, sorbitol, sucrose, xylose, calcium carbonate, BHT, hexane, potassium persulfate, 2,2-azinobis (ethyl-2,3-dihydrobenzothiazoline-6-sulphonic acid) diammonium salt (ABTS), Trolox were purchased from Sigma-Aldrich GmbH (Steinheim, Germany); 99.8\% trifluoracetic acid, chlorogenic acid, hyperoside, isoquercitrin, rutin, astragalin were purchased from Carl Roth GmbH (Karlsruhe, Germany); 96.3\% ethanol was purchased from Stumbras SC (Kaunas, Lithuania). Purified deionized water $(18.2 \mathrm{~m} \Omega / \mathrm{cm})$ was produced using the Millipore (Burlington, MA., USA) water purification system. 
Table 5. Description of tested rowanberry species and cultivars.

\begin{tabular}{|c|c|}
\hline Cultivar & Species \\
\hline Alaja Krupnaja & Sorbus aucuparia \\
\hline Burka & Sorbus aucuparia $\times$ Sorbaronia alpina $[$ Sorbus aria $\times$ Aronia arbutifolia] \\
\hline Businka & Sorbus aucuparia var. rossica \\
\hline Dodong & Sorbus ulleungensis \\
\hline Esseziani & Sorbus esseziani \\
\hline Fructo Lutea & Sorbus aucuparia var. xanthocarpa \\
\hline Granatnaja & Sorbus aucuparia $\times$ Crataegus sanguinea \\
\hline Kirsten Pink & Sorbus $\times$ arnoldiana $[$ Sorbus aucuparia $\times$ Sorbus discolor $]$ \\
\hline Konzentra & Sorbus aucuparia \\
\hline Krasnaja Krupnoplodnaja & Sorbus aucuparia var. moravica \\
\hline Likernaja & Sorbus aucuparia $\times$ Aronia melanocarpa \\
\hline Miciurinskaja Desertnaja & [Sorbus aucuparia $\times$ Aronia melanocarpa] $\times$ Mespilus germanica \\
\hline Nevezinskaja & Sorbus aucuparia \\
\hline Pendula Variegata & Sorbus aucuparia \\
\hline Red Tip & Sorbus $\times$ arnoldiana $[$ Sorbus aucuparia $\times$ Sorbus discolor $]$ \\
\hline Rosina Variegata & Sorbus aucuparia var. moravica \\
\hline Rubinovaja & Sorbus aucuparia $\times$ pollen from Pyrus species \\
\hline Sorbinka & Sorbus aucuparia \\
\hline Titan & Burka $\times$ mixture of pollen from Malus sp. and Pyrus sp. \\
\hline White Swan & Sorbus $\times$ arnoldiana $[$ Sorbus aucuparia $\times$ Sorbus discolor] \\
\hline
\end{tabular}

\subsection{Sample Preparation}

\subsubsection{Extraction of Phenolic Compounds}

The fruit powder samples were weighed each to $1.0 \mathrm{~g}$ (accurate sample) and were then placed into a conical flask with $12 \mathrm{~mL}$ of $70 \%$ ethanol and extracted in an Elmasonic P $120 \mathrm{H}$ ultrasonic bath (Singen, Germany) for $10 \mathrm{~min}$. The extraction procedures were repeated three times. The extracts were centrifuged for $5 \mathrm{~min}$ at $8500 \mathrm{rpm}$ in a Biofuge stratos centrifuge (Hanau, Germany) The extracts obtained were filtered through a paper filter into a $50 \mathrm{~mL}$ volumetric flask, hydrochloric acid was added up to $0.1 \% v / v$, and adjusted according to volume with $70 \%$ ethanol.

\subsubsection{Extraction of Sugars and Organic Acids}

The fruit powder samples were weighed each to1.0 $\mathrm{g}$ (accurate sample) and were then placed into a conical flask with $15 \mathrm{~mL}$ of distilled water and extracted in an Elmasonic P $120 \mathrm{H}$ ultrasonic bath for $10 \mathrm{~min}$. The extraction procedures were repeated three times. The extracts were centrifuged for $5 \mathrm{~min}$ at $8500 \mathrm{rpm}$ in a Biofuge stratos centrifuge and the extracts obtained were filtered through a paper filter into a $50 \mathrm{~mL}$ volumetric flask. All prepared extracts were filtered through a membrane filter with a pore size of $0.22 \mu \mathrm{m}$ (Carl Roth $\mathrm{GmbH})$.

\subsubsection{Extraction of Carotenoids}

Carotenoids were determined by the method described by Hallmann et al., 2011 with some modifications [39]. The fruit powder samples were weighed each to $0.2 \mathrm{~g}$ (accurate sample). The weighed fruit powder sample was then placed into a conical flask with $100 \mathrm{mg}$ of calcium carbonate and $10 \mathrm{~mL}$ of $0.1 \%$ BHT in hexane and extracted in an Elmasonic P $120 \mathrm{H}$ ultrasonic bath for $30 \mathrm{~min}$. The extraction procedures were repeated three times Filtrates were combined and adjusted according to $20 \mathrm{~mL}$ volume with $0.1 \%$ BHT in hexane. $5 \mathrm{~mL}$ of extract was evaporated to dryness under the steam of nitrogen. Residuals were dissolved in $1.8 \mathrm{~mL}$ of acetonitrile before HPLC analysis. 


\subsection{Qualitative and Quantitative Analysis}

\subsubsection{HPLC Methods}

Qualitative and quantitative analysis of flavonols and phenolic acid, anthocyanins, $\beta$-carotene and organic acid were performed using a Waters 2695 Alliance system (Waters, Milford, MA, USA) equipped with a Waters 2998 photodiode array detector. Qualitative and quantitative analysis of sugars was performed using the Waters 2695 Alliance system equipped with a Waters 2424 evaporative light-scattering detector.

Separation of flavonols and phenolic acid was performed according to the methodology described by Gaivelyte et al. [40,41] using an ACE (ACT, Aberdeen, UK) column (C18, $150 \mathrm{~mm} \times 4.6 \mathrm{~mm}$, particle size $3 \mu \mathrm{m})$. The mobile phase of the optimized chromatographic method consisted of eluent $\mathrm{A}$ $(0.05 \%$ trifluoracetic acid) and $\mathrm{B}$ (acetonitrile). The gradient variation consisted of: $0-5 \mathrm{~min}-12 \% \mathrm{~B}$, $5-50 \mathrm{~min}-12-30 \% \mathrm{~B}, 50-51 \mathrm{~min}-30-90 \% \mathrm{~B}, 51-56 \mathrm{~min}-90 \% \mathrm{~B}, 57 \mathrm{~min}-12 \% \mathrm{~B}$. Eluent flow rate was $0.5 \mathrm{~mL} / \mathrm{min}$, and injection volume $10 \mu \mathrm{L}$. The column was temperature-controlled, maintained at $25^{\circ} \mathrm{C}$. Validation parameters-linearity and range of linearity, limits of detection and limits of quantification, intra-day repeatability and intermediate precisions, were assessed according to the ICH guidelines. The results of validation were described in our previous studies [40-42].

Separation of anthocyanins was performed according to the methodology described in European Pharmacopoeia, 2016 using an ACE column (C18, $250 \mathrm{~mm} \times 4.6 \mathrm{~mm}$, particle size $5 \mu \mathrm{m})$. The mobile phase of the chromatographic method consisted of eluent A ( $0.05 \%$ formic acid) and B (formic acid, acetonitrile, methanol, water, (8.5:22.5:22.5:41.5 v/v/v/v)). The gradient variation consisted of: 0-35 min-7-25\% B, 35-45 min-25-65\% B, 45-46 min-65-100\% B, 46-50 min - 100\% B, $51 \mathrm{~min}-7 \%$ B. Eluent flow rate was $1 \mathrm{~mL} / \mathrm{min}$, and injection volume $10 \mu \mathrm{L}$. The column was temperature-controlled, maintained at $25^{\circ} \mathrm{C}$ [43].

Separation of $\beta$-carotene was performed using an ACE column $(\mathrm{C} 18,250 \mathrm{~mm} \times 4.6 \mathrm{~mm}$, particle size $5 \mu \mathrm{m})$. The mobile phase of the optimized chromatographic method consisted of eluent $\mathrm{A}$ (acetonitrile, $0.25 \%$ trimethylamine in water $(9: 1 \mathrm{v} / v))$ and B $(0.25 \%$ trimethylamine in ethyl acetate). The gradient variation consisted of: 0-10 $\mathrm{min}-10-50 \% \mathrm{~B}, 10-20 \mathrm{~min}-50-90 \% \mathrm{~B}, 20-25 \mathrm{~min}-90 \% \mathrm{~B}$, $25-26 \mathrm{~min}-90-10 \% \mathrm{~B}$. Eluent flow rate was $1 \mathrm{~mL} / \mathrm{min}$, and injection volume $10 \mu \mathrm{L}$. The column was temperature-controlled, maintained at $25^{\circ} \mathrm{C}$.

Separation of organic acids was performed using a Shodex RSpak KC-811 (Showa Denko KK, Tokyo, Japan) column $(300 \mathrm{~mm} \times 8.0 \mathrm{~mm})$. The mobile phase of the optimized chromatographic method consisted of $1 \mathrm{mM}$ perchloric acid. Eluent flow rate was $1 \mathrm{~mL} / \mathrm{min}$, and injection volume $10 \mu \mathrm{L}$. The column was temperature-controlled, maintained at $60{ }^{\circ} \mathrm{C}$.

Separation of sugars was performed using a Shodex SUGAR SZ5532 (Showa Denko KK) column $(150 \mathrm{~mm} \times 6.0 \mathrm{~mm})$. The mobile phase of the optimized chromatographic method consisted of eluent A (water) and B (acetonitrile). The gradient variation consisted of: 0-5 min-81\% B, 5-20 min-81-70\% B, 20-22 min-70\% B, $23 \mathrm{~min}-81 \%$ B. Eluent flow rate was $1 \mathrm{~mL} / \mathrm{min}$, and injection volume $10 \mu \mathrm{L}$. The column was temperature-controlled, maintained at $60^{\circ} \mathrm{C}$. Nitrogen was used as the ELSD nebuliser gas (25 psi), tube temperature was set to $60{ }^{\circ} \mathrm{C}$.

Chromatographic peak identification was carried out according to the analyte and reference compound retention time, by comparing the UV absorption spectra of the reference compounds and analytes obtained with a diode array detector, as well as by applying UPLC-QTOF-MS analysis described in our previous study [44]. Caffeoylshikimic acid, coumaroylshikimic acid, dicaffeoylquinic acid, and quercetin dihexosides were identified using UPLC-QTOF assay and quantification was performed using chlorogenic acid and rutin calibration curves. The purity of the peaks was assessed on the basis of their UV/VIS absorption spectra at 200-600 nm Quantitative assessment of the analytes was performed based on the analyte peak area dependence on analyte concentration in the test solution. Calibration curves of compounds identified in the fruit extracts were constructed using standard solutions (Table 6). 
Table 6. Parameters of calibration curves of standard compounds.

\begin{tabular}{cccc}
\hline Compound & $\begin{array}{c}\text { Tested Linear Range } \\
(\mathbf{m g} / \mathbf{m L})\end{array}$ & $\begin{array}{c}\text { Calibration Curve } \\
\text { Equation }\end{array}$ & $\begin{array}{c}\text { Determination } \\
\text { Coefficient }\end{array}$ \\
\hline Neochlorogenic & $3.369-107.8$ & $\mathrm{y}=36,200 \mathrm{x}-6330$ & 0.9997 \\
Chlorogenic acid & $1.4654-93.734$ & $\mathrm{y}=61,500 \mathrm{x}-32,800$ & 0.9998 \\
Cryptochlorogenic acid & $0.977-125$ & $\mathrm{y}=43,800 \mathrm{x}-8150$ & 0.9997 \\
Rutin & $0.158-10.078$ & $\mathrm{y}=50,900 \mathrm{x}-2670$ & 0.9999 \\
Hyperoside & $0.170-9.600$ & $\mathrm{y}=61,600 \mathrm{x}-4920$ & 0.9998 \\
Isoquercitrin & $0.170-10.892$ & $\mathrm{y}=40,200 \mathrm{x}-2510$ & 0.9999 \\
Quercetin-malonylglucoside & $0.332-42.500$ & $\mathrm{y}=24,800 \mathrm{x}-893$ & 0.9999 \\
Isorhamnetin rutinoside & $0.488-15.625$ & $\mathrm{y}=36,500 \mathrm{x}+1580$ & 0.9999 \\
Astragalin & $0.168-10.754$ & $\mathrm{y}=35,200 \mathrm{x}-2710$ & 0.9999 \\
Cyanidin-3-galactoside & $3.54-88.46$ & $\mathrm{y}=25,800,000 \mathrm{x}$ & 0.9990 \\
Cyanidin-3-glucoside & $3.99-99.93$ & $\mathrm{y}=26,100,000 \mathrm{x}$ & 0.9988 \\
Cyanidin-3-arabinoside & $2.81-70.35$ & $\mathrm{y}=27,100,000 \mathrm{x}$ & 0.9992 \\
Peonidin-3-arabinoside & $0.25-6.14$ & $\mathrm{y}=27,200,000 \mathrm{x}$ & 0.9981 \\
Malvidin-3-arabinoside & $0.93-23.12$ & $\mathrm{y}=24,800,000 \mathrm{x}$ & 0.9979 \\
$\beta$-carotene & $3.07-98.5$ & $\mathrm{y}=21,100 \mathrm{x}-3880$ & 0.9997 \\
Xylose & $0.0625-2$ & $\mathrm{y}=1.91 \mathrm{x}+5.30$ & 0.9987 \\
Fructose & $0.625-10$ & $\mathrm{y}=1.77 \mathrm{x}+5.18$ & 0.9984 \\
Glucose & $0.25-4$ & $\mathrm{y}=1.76 \mathrm{x}+5.20$ & 0.9976 \\
Sucrose & $0.25-4$ & $\mathrm{y}=1.71 \mathrm{x}+5.45$ & 0.9993 \\
Sorbitol & $0.0625-1$ & $\mathrm{y}=1.74 \mathrm{x}+5.31$ & 0.9985 \\
Ascorbic acid & $0.1-0.5$ & $\mathrm{y}=19,100 \mathrm{x}+41,000$ & 0.9990 \\
Malic acid & $0.5-2.0$ & $\mathrm{y}=599 \mathrm{x}+38.9$ & 0.9999 \\
\hline
\end{tabular}

The specificity was determined based on the retention time of analyte and standard compound, UV spectra and spiking the sample. Contents of phenolic acids were calculated at a wavelength of $325 \mathrm{~nm}$, while the contents of flavonoids were calculated at a wavelength of $350 \mathrm{~nm}$. Contents of anthocyanins were calculated at a wavelength of $535 \mathrm{~nm}$, contents of $\beta$-carotene were calculated at a wavelength of $450 \mathrm{~nm}$, contents of organic acids were calculated at a wavelength of $210 \mathrm{~nm}$.

\subsubsection{Spectrophotometric Methods}

The spectrophotometric analysis was performed using a Spectronic Camspec M550 spectrophotometer (Spectronic Camspec Ltd., Garforth, UK).

Determination of total carotenoid content. The absorbance of the extracts was measured at $450 \mathrm{~nm}$. The content of carotenoids was calculated from the $\beta$-carotene calibration curve and expressed as $\beta$-carotene equivalents in $\mu \mathrm{g} / \mathrm{g} \mathrm{DW}$ of fruit.

Determination of antioxidant activity was performed using an $\mathrm{ABTS}^{+}$radical cation decolourization assay according to the methodology described by Re et al. [45]. A volume of $3 \mathrm{~mL}$ of $\mathrm{ABTS}^{+}$solution (absorbance $1.00 \pm 0.005$ ) was mixed with $20 \mu \mathrm{L}$ of the ethanol extract of fruit powder. A decrease in absorbance was at a wavelength of $734 \mathrm{~nm}$ after keeping the samples for $60 \mathrm{~min}$ in the dark. Antioxidant activity was expressed as Trolox equivalents (TE) in $\mu \mathrm{mol} / \mathrm{g}$ DW of fruit.

\subsection{Statistical Analysis}

The amount of phenolic compounds is expressed as a mean \pm standard deviation (SD) of three replicates. The statistical data analysis was evaluated by applying the ANOVA with Tukey HSD post- hoc test. Significant different means were marked with different letters. Differences were considered statistically significant when $p<0.05$. The principal component analysis was performed. The adequacy of the data was ensured by using Bartlett's test of sphericity and the Kaiser-Meyer-Olkin measure of sampling adequacy. Factors with eigenvalues greater than 1 were taken into account. Hierarchical cluster analysis was performed using the between group linkage method with squared 
Euclidean distances. The data were processed using Microsoft Office Excel 2010 (Microsoft, Redmond, WA, USA) and SPSS 20 (IBM, Armonk, NY, USA) software.

\section{Conclusions}

The phytochemical profiles of rowanberries vary significantly and are cultivar-specific. On the basis of the determined chemical composition and antioxidant activity, rowanberry powders can be regarded as a rich source of health promoting substances-carotenoids, flavonoids, phenolic acids, anthocyanins, sorbitol and ascorbic acid. The phytochemical profiles covering the compositions of bioactive compounds of different classes could be used in authenticity tests detecting the adulterations with other types of fruits. Cultivars 'Burka', 'Likernaja', 'Dodong', and 'Fructo Lutea' distinguish themselves with exclusive phytochemical composition and high antioxidant activity, as well. These cultivars could be selected as suitable raw materials for preparation of rowanberry fruit powders. Qualitatively prepared rowanberry powders with comprehensively defined phytochemical composition could be applied in the production of smart and innovative nutraceuticals or functional food ingredients.

Author Contributions: K.Z., L.R., R.R., M.M., L.I. and V.J. conceived and designed the experiments; K.Z., L.R., R.R. and M.M. performed the experiments; K.Z., L.R., R.R. analyzed the data; L.I. and V.J. contributed reagents/materials/analysis tools; K.Z. and L.R. wrote the paper.

Funding: This research received no external funding.

Acknowledgments: The authors wish to thank the LSMU Science Foundation for the support of this study.

Conflicts of Interest: The authors declare no conflict of interest.

\section{References}

1. Aldasoro, J.J.; Aedo, C.; Navarro, C.; Garmendia, F.M. The Genus Sorbus (Maloideae, Rosaceae) in Europe and in North Africa: Morphological Analysis and Systematics. Syst. Bot. 1998, 23, 189-212. [CrossRef]

2. Baltacioglu, C.; Velioglu, S.; Karacabey, E. Changes in total phenolic and flavonoid contents of rowanberry fruit during posthatvest storage. J. Food Qual. 2011, 34, 278-283. [CrossRef]

3. Berna, E.; Kampuse, S.; Dukalska, L.; Murniece, I. The chemical and physical properties of sweet rowanberries in powder sugar. In Proceedings of the 6th Baltic Conference on Food Science and Technology FOODBALT-2011, Jelgava, Latvia, 5-6 May 2011.

4. Hukkanen, A.T.; Pölönen, S.S.; Kärenlampi, S.O.; Kokko, H.I. Antioxidant Capacity and Phenolic Content of Sweet Rowanberries. J. Agric. Food Chem. 2006, 54, 112-119. [CrossRef] [PubMed]

5. Poyrazoglu, E.S. Changes in ascorbic acid and sugar content of rowanberries during ripening. J. Food Qual. 2004, 27, 366-370. [CrossRef]

6. Gil-Izquierdo, A.; Mellenthin, A. Identification and quantitation of flavonols in rowanberry (Sorbus aucuparia L.) juice. Eur. Food Res. Technol. 2001, 213, 12-17.

7. Jurikova, T.; Sochor, J.; Mlcek, J.; Balla, S.; Klejdus, B.; Baron, M.; Ercisli, S.; Yilmaz, S.O. Polyphenolic profile of interspecific crosses of rowan (Sorbus aucuparia L.). Ital. J. Food Sci. 2014, 26, 317-324.

8. Kylli, P.; Nohynek, L.; Puupponen-Pimiä, R.; Westerlund-Wikström, B.; McDougall, G.; Stewart, D.; Heinonen, M. Rowanberry Phenolics: Compositional Analysis and Bioactivities. J. Agric. Food Chem. 2010, 58, 11985-11992. [CrossRef] [PubMed]

9. Yu, T.; Lee, Y.J.; Jang, H.-J.; Kim, A.R.; Hong, S.; Kim, T.W.; Kim, M.-Y.; Lee, J.; Lee, Y.G.; Cho, J.Y. Anti-inflammatory activity of Sorbus commixta water extract and its molecular inhibitory mechanism. J. Ethnopharmacol. 2011, 134, 493-500. [CrossRef] [PubMed]

10. Olszewska, M.A.; Michel, P. Antioxidant activity of inflorescences, leaves and fruits of three Sorbus species in relation to their polyphenolic composition. Nat. Prod. Res. 2009, 23, 1507-1521. [CrossRef] [PubMed]

11. Grussu, D.; Stewart, D.; McDougall, G.J. Berry Polyphenols Inhibit $\alpha$-Amylase in vitro: Identifying Active Components in Rowanberry and Raspberry. J. Agric. Food Chem. 2011, 59, 2324-2331. [CrossRef] [PubMed]

12. Mikulic-Petkovsek, M.; Krska, B.; Kiprovski, B.; Veberic, R. Bioactive Components and Antioxidant Capacity of Fruits from Nine Sorbus Genotypes. J. Food Sci. 2017, 82, 647-658. [CrossRef] [PubMed] 
13. Rocchetti, G.; Chiodelli, G.; Giuberti, G.; Ghisoni, S.; Baccolo, G.; Blasi, F.; Montesano, D.; Trevisan, M.; Lucini, L. UHPLC-ESI-QTOF-MS profile of polyphenols in Goji berries (Lycium barbarum L.) and its dynamics during in vitro gastrointestinal digestion and fermentation. J. Funct. Foods 2018, 40, 564-572. [CrossRef]

14. Raudone, L.; Raudonis, R.; Liaudanskas, M.; Viskelis, J.; Pukalskas, A.; Janulis, V. Phenolic Profiles and Contribution of Individual Compounds to Antioxidant Activity of Apple Powders. J. Food Sci. 2016, 81, 1055-1061. [CrossRef] [PubMed]

15. Fiedor, J.; Burda, K. Potential role of carotenoids as antioxidants in human health and disease. Nutrients 2014, 6, 466-488. [CrossRef] [PubMed]

16. Fattore, M.; Montesano, D.; Pagano, E.; Teta, R.; Borrelli, F.; Mangoni, A.; Seccia, S.; Albrizio, S. Carotenoid and flavonoid profile and antioxidant activity in "Pomodorino Vesuviano" tomatoes. J. Food Compos. Anal. 2016, 53, 61-68. [CrossRef]

17. Raudonis, R.; Raudonè, L.; Gaivelytė, K.; Viškelis, P.; Janulis, V. Phenolic and antioxidant profiles of rowan (Sorbus L.) fruits. Nat. Prod. Res. 2014, 28, 1231-1240. [CrossRef] [PubMed]

18. Liang, N.; Kitts, D. Role of Chlorogenic Acids in Controlling Oxidative and Inflammatory Stress Conditions. Nutrients 2015, 8, 16. [CrossRef] [PubMed]

19. Upadhyay, R.; Mohan Rao, L.J. An Outlook on Chlorogenic Acids-Occurrence, Chemistry, Technology, and Biological Activities. Crit. Rev. Food Sci. Nutr. 2013, 53, 968-984. [CrossRef] [PubMed]

20. Mikulic-Petkovsek, M.; Schmitzer, V.; Slatnar, A.; Stampar, F.; Veberic, R. Composition of Sugars, Organic Acids, and Total Phenolics in 25 Wild or Cultivated Berry Species. J. Food Sci. 2012, 77, C1064-C1070. [CrossRef] [PubMed]

21. Kampuss, K.; Kampuse, S.; Berna, E.; Kruma, Z.; Krasnova, I.; Drudze, I. Biochemical composition and antiradical activity of rowanberry (Sorbus L.) cultivars and hybrids with different Rosaceae L. cultivars. Latvian J. Agron. 2009, 12, 59-65. (In Polish)

22. Tomás-Barberán, F.A.; Espín, J.C. Phenolic compounds and related enzymes as determinants of quality in fruits and vegetables. J. Sci. Food Agric. 2001, 81, 853-876. [CrossRef]

23. Ratti, C. Freese drying for food powder production. In Handbook of Food Powders, 1st ed.; Bhandari, B., Bansal, N., Zhang, M., Schuck, P., Eds.; Woodhead Publishing Limited: Oxford, UK, 2013; pp. 57-84, ISBN 978-0-85709-513-8.

24. De Boer, A.; Urlings, M.J.E.; Bast, A. Active ingredients leading in health claims on functional foods. J. Funct. Foods 2016, 20, 587-593. [CrossRef]

25. Razina, T.G.; Zueva, E.P.; Ulrich, A.V.; Rybalkina, O.Y.; Chaikovskii, A.V.; Isaikina, N.V.; Kalinkina, G.I.; Zhdanov, V.V.; Zyuz'kov, G.N. Antitumor Effects of Sorbus aucuparia L. Extract Highly Saturated with Anthocyans and Their Mechanisms. Bull. Exp. Biol. Med. 2016, 162, 93-97. [CrossRef] [PubMed]

26. Clifford, M.N. Chlorogenic acids and other cinnamates-Nature, occurrence and dietary burden. J. Sci. Food Agric. 1999, 79, 362-372. [CrossRef]

27. Mattila, P.; Hellström, J.; Törrönen, R. Phenolic Acids in Berries, Fruits, and Beverages. J. Agric. Food Chem. 2006, 54, 7193-7199. [CrossRef] [PubMed]

28. Tsuda, T.; Ueno, Y.; Kojo, H.; Yoshikawa, T.; Osawa, T. Gene expression profile of isolated rat adipocytes treated with anthocyanins. Biochim. Biophys. Acta 2005, 1733, 137-147. [CrossRef] [PubMed]

29. Li, D.; Zhang, Y.; Liu, Y.; Sun, R.; Xia, M. Purified Anthocyanin Supplementation Reduces Dyslipidemia, Enhances Antioxidant Capacity, and Prevents Insulin Resistance in Diabetic Patients. J. Nutr. 2015, 145, 742-748. [CrossRef] [PubMed]

30. Nakaishi, H.; Matsumoto, H.; Tominaga, S.; Hirayama, M. Effects of black current anthocyanoside intake on dark adaptation and VDT work-induced transient refractive alteration in healthy humans. Altern. Med. Rev. 2000, 5, 553-562. [PubMed]

31. Seeram, N.; Momin, R.A.; Nair, M.G.; Bourquin, L.D. Cyclooxygenase inhibitory and antioxidant cyanidin glycosides in cherries and berries. Phytomedicine 2001, 8, 362-369. [CrossRef] [PubMed]

32. Azimova, S.S.; Glushenkova, A.I. Sorbus aucuparia L. (S. boissieri Schneid.). In Lipids, Lipophilic Components and Essential Oils from Plant Sources; Azimova, S.S., Glushenkova, A.I., Eds.; Springer: London, UK, 2012; pp. 778-779.

33. Montesano, D.; Rocchetti, G.; Putnik, P.; Lucini, L. Bioactive profile of pumpkin: An overniew on terpenoids and their health-promoting properties. Curr. Opin. Food Sci. 2018, 22, 81-87. [CrossRef] 
34. Lin, T.M.; Durance, T.D.; Scaman, C.H. Characterization of vacuum microwave, air and freeze dried carrot slices. Food Res. Int. 1998, 31, 111-117. [CrossRef]

35. Viljakainen, S.; Visti, A.; Laakso, S. Concentrations of Organic Acids and Soluble Sugars in Juices from Nordic Berries. Acta Agric. Scand. Sect. B Soil Plant Sci. 2002, 52, 101-109. [CrossRef]

36. Chukwuma, C.I.; Islam, M.S. Sorbitol increases muscle glucose uptake ex vivo and inhibits intestinal glucose absorption ex vivo and in normal and type 2 diabetic rats. Appl. Physiol. Nutr. Metab. 2017, 42, 377-383. [CrossRef] [PubMed]

37. Skrovankova, S.; Sumczynski, D.; Mlcek, J.; Jurikova, T.; Sochor, J. Bioactive Compounds and Antioxidant Activity in Different Types of Berries. Int. J. Mol. Sci. 2015, 16, 24673-24706. [CrossRef] [PubMed]

38. Shofian, N.M.; Hamid, A.A.; Osman, A.; Saari, N.; Anwar, F.; Dek, M.S.P.; Hairuddin, M.R. Effect of freeze-drying on the antioxidant compounds and antioxidant activity of selected tropical fruits. Int. J. Mol. Sci. 2011, 12, 4678-4692. [CrossRef] [PubMed]

39. Hallmann, E.; Orpel, E.; Rembiałkowska, E. The Content of Biologically Active Compounds in Some Fruits from Natural State. Veg. Crop. Res. Bull. 2011, 75, 81-90. [CrossRef]

40. Gaivelyte, K.; Jakstas, V.; Razukas, A.; Janulis, V. Variation in the contents of neochlorogenic acid, chlorogenic acid and three quercetin glycosides in leaves and fruits of Rowan (Sorbus) species and varieties from collections in Lithuania. Nat. Prod. Commun. 2013, 8, 1105-1110. [PubMed]

41. Gaivelyte, K. Research of Phenolic Compounds in Plants of Genus Sorbus L. Ph.D. Thesis, Lithuanian University of Health Sciences, Kaunas, Lithuania, 2014.

42. Gaivelyte, K.; Jakstas, V.; Razukas, A.; Janulis, V. Variation of quantitative composition of phenolic compounds in rowan (Sorbus aucuparia L.) leaves during the growth season. Nat. Prod. Res. 2014, 28, 1018-1020. [CrossRef] [PubMed]

43. Council of Europe. European Pharmacopoeia, 9th ed.; Council of Europe: Strasbourg, France, 2016.

44. Raudone, L.; Raudonis, R.; Gaivelyte, K.; Pukalskas, A.; Viškelis, P.; Venskutonis, P.R.; Janulis, V. Phytochemical and antioxidant profiles of leaves from different Sorbus L. species. Nat. Prod. Res. 2015, 29, 281-285. [CrossRef] [PubMed]

45. Re, R.; Pellegrini, N.; Proteggente, A.; Pannala, A.; Yang, M.; Rice-Evans, C. Antioxidant activity applying an improved ABTS radical cation decolorization assay. Free Radic. Biol. Med. 1999, 26, 1231-1237. [CrossRef]

Sample Availability: Samples of the compounds are available from the authors.

(C) 2018 by the authors. Licensee MDPI, Basel, Switzerland. This article is an open access article distributed under the terms and conditions of the Creative Commons Attribution (CC BY) license (http://creativecommons.org/licenses/by/4.0/). 